Jurnal Civics: Media Kajian Kewarganegaraan
https://journal.uny.ac.id/index.php/civics/index
$1829-5789$ (print)
$2541-1918$ (online)

\title{
Peran partai politik dalam meningkatkan partisipasi politik kader perempuan melalui pendidikan politik
}

\author{
Hariyanti $^{\text {a, }}{ }^{*}$, Cecep Darmawan ${ }^{\text {b, } 2}$, Iim Siti Masyitoh ${ }^{\text {c, } 3}$ \\ ${ }^{a}$ Sekolah Pascasarjana, Universitas Pendidikan Indonesia, Bandung, Indonesia \\ ${ }^{b, c}$ Fakultas Pendidikan Ilmu Pengetahuan Sosial, Universitas Pendidikan Indonesia, Bandung, \\ Indonesia \\ ${ }^{1}$ hari_yanti@student.upi*; ${ }^{2}$ cecepdarmawan@yahoo.com; ${ }^{3}$ iim.sitimasyitoh@upi.edu \\ *korespondensi penulis
}

\begin{tabular}{ll}
\hline \multicolumn{2}{l}{ Informasi artikel } \\
\hline Sejarah artikel: & \\
Diterima & $: 29-12-2017$ \\
Revisi & $: 06-03-1218$ \\
Dipublikasikan & $: 31-05-2018$ \\
\hline
\end{tabular}

Kata kunci:

Partai politik

Partisipasi politik perempuan

Pendidikan politik

Partai Nasdem

\begin{abstract}
ABSTRAK
Partai politik mempunyai kewajiban yuridis dan moral untuk melaksanakan pendidikan politik khususnya memberdayakan kader perempuan di tengah minimnya partisipasi politik perempuan. Penelitian ini menggunakan pendekatan kualitatif dengan metode deskriptif. Penentuan informan penelitian melalui teknik non probability sampling dengan teknik purposive sampling. Teknik pengujian keabsahan data menggunakan triangulasi sumber data. Temuan penelitian menunjukkan bahwa kendala-kendala pendidikan politik kader perempuan, yakni (1) kendala internal, yang berasal dalam diri kader perempuan; (2) kendala eksternal, stereotip dalam konstruksi sosial budaya masyarakat; (3) keseriusan partai dalam memberdayakan kader perempuan; (4) kelemahan regulasi peraturan perundangundangan. Partai politik melakukan beberapa upaya untuk mengatasi kendala tersebut melalui pendekatan personal, menggagas konsep tanpa mahar politik; membentuk regulasi internal partai politik yang akomodatif terhadap kebutuhan perempuan.
\end{abstract}

\section{Keywords:}

Political party

Women's political participation

Political education

Nasdem Party

\section{ABSTRACT}

The role of political parties in increasing the political participation of women through political education. Political parties have moral as well as juridical obligation to conduct political education especially for women cadres in the low level of political participation among women. It was a qualitative research with descriptive method of explanation. The informant involved was selected with non-probability sampling, purposive sampling. The results reveal the obstacles faced by women cadres are (1) internal obstacles, coming from the cadres themselves; (2) external obstacles, coming from stereotype upholding by among cultural and society members; (3) the seriousness of political party to empower their own women cadres; (4) the weakness of the law concerning this issue. To overcome the problems, political parties is doing effort such as personal approach, politic without political 'bride price' (mahar politik), issuing internal regulation accommodative to the needs of women.

Copyright $\odot 2018$ Hariyanti, dkk 



\section{Pendahuluan}

Pendidikan politik merupakan sesuatu yang niscaya dalam sebuah negara demokrasi. Warga negara perlu mendapatkan pengetahuan dan pemahaman bahkan pencerahan seputar persoalan politik yang terjadi. Partai politik melaksanakan fungsi Pendidikan politik, yang bertujuan untuk membentuk kepribadian politik, kesadaran politik dan partisipasi politik (Ruslan, 2000). Muara dari pendidikan politik adalah tingginya partisipasi politik kader dalam proses politik praktis. Partai politik merupakan sebuah keniscayaan dalam negara demokrasi karena berfungsi sebagai sarana sosialisasi politik dan partisipasi politik rakyat. Clinton Rossiter (dalam Katz \& Crotty, 2014) menyatakan bahwa tidak ada demokrasi tanpa politik, dan tidak ada politik tanpa partai. Pendidikan politik yang diberikan secara optimal tentu berimplikasi kepada peningkatan literasi politik warganegara.

Pendidikan politik diberikan dalam kerangka pendidikan kewarganegaraan sebab dalam pendidikan politik oleh partai politik ditujukan tidak hanya mempersiapkan kader menjadi politisi yang loyal terhadap partai tetapi untuk manfaat jangka panjang, yakni membentuk seorang negarawan yang arif dan bijak dalam bersikap dan berperilaku terhadap berbagai persoalan kebangsaan. Pendidikan politik yang dikaji dalam penelitian ini tidak hanya bagi kader perempuan yang duduk dalam lembaga perwakilan rakyat tetapi juga kader perempuan biasa. Pendidikan politik dalam kerangka pendidikan kewarganegaraan sejalan dengan pendapat Branson \& Quigley (1998) bahwa karakteristik warga negara melek politik adalah kompetensi kewarganegaraan (civic competence) yang disebutkan dalam tiga komponen penting yaitu (1) civic knowledge yakni pengetahuan dan wawasan kewarganegaraan; (2) civic disposition yakni nilai, sikap dan komitmen kewarganegaraan; (3) civic skill yaitu perangkat keterampilan intelektual, sosial dan personal kewarganegaraan yang seyogianya dikuasai oleh warga negara guna menjadi warga negara yang baik dan cerdas (to be a good and smart citizen) sebagaimana yang dicitakan oleh negara. Pengetahuan dan pemahaman politik yang jelas akan melahirkan kesadaran politik warga negara dalam menjalankan hak dan kewajibannya sebagai warga negara serta menuntunnya dalam bersikap dan menanggapi persoalan sosial politik di sekitarnya.

Pendidikan politik diberikan untuk mengasah keterampilan politik kader sehingga dapat berpartisipasi aktif dalam kegiatan kepartaian maupun di lembaga legislatif sebagai wujud tanggung jawabnya kepada masyarakat, partai politik dan konstituen. Predescu \& Darjan (2010, p. 3241) menyatakan bahwa "political participation requires knowledge about political topics, skills of using political tools and possession of adequate procedures. Also, the political participation implies the manifestation of a positive attitude toward politic". Jadi, pengetahuan politik dibutuhkan dalam politik praktis sehingga aktivitas yang dilakukan tidak semu, artinya partisipasi berkualitas dan berpengaruh dalam proses pengambilan keputusan publik. Upaya peningkatan partisipasi politik kader perempuan melalui pendidikan politik berada dalam kerangka keterampilan kewarganegaraan (civic skill). Partisipasi merupakan bentuk-bentuk tindakan berupa keaktifan kader perempuan dalam kegiatan kepartaian dan pemerintahan yang didorong oleh kesadaran dan pengetahuan politik yang dimiliki sehingga partisipasi yang dihasilkan bukanlah partisipasi semu. Keterampilan kewarganegaraan (civic skills) yang diberikan dalam program pendidikan politik partai meliputi keterampilan intelektual (intellectual skills) dan keterampilan berpartisipasi (participatory skills) dalam kehidupan berbangsa dan bernegara (Muchtarom, 2012). Oleh karena itu, pendidikan politik penting diberikan kepada warga negara. Terkait dengan beberapa pihak yang memiliki kewajiban yuridis maupun moral dalam melakukan pendidikan politik kepada warga negara, beberapa peraturan perundangundangan telah mengaturnya. Salah satunya 
dibebankan kepada partai politik. Pamungkas \& Parlindungan (2011, hal. 5) mendefinisikan partai politik adalah sebuah organisasi untuk memperjuangkan nilai dan ideologi tertentu melalui penguasaan struktur kekuasaan dan kekuasaan itu diperoleh melalui keikutsertaannya di dalam pemilihan umum. Partai politik merupakan sebuah keniscayaan dalam negara demokrasi karena berfungsi sebagai sarana sosialisasi politik dan partisipasi politik rakyat.

Pendidikan politik oleh partai memainkan peranan strategis dalam membentuk warga negara terutama kader partai guna memiliki kepribadian politik, kesadaran politik dan mampu berpartisipasi secara aktif dan responsif sebab kader merupakan bagian dari aktor politik praktis yang terlibat dalam sirkulasi kekuasaan publik. Utamanya terhadap kader perempuan, pendidikan politik oleh partai dapat menjadi batu loncatan untuk meningkatkan partisipasi politik kader perempuan baik di tataran internal partai maupun di pemerintahan. Partisipasi politik kader perempuan partai di Indonesia masih relatif rendah. Salah satunya dapat dilihat dari kuantitas perempuan yang terwakili di lembaga legislatif. Hasil penelitian Pusat Kajian Politik Universitas Indonesia tahun 2014 mengungkapkan bahwa keterwakilan perempuan dalam parlemen di Indonesia tidak pernah melebihi angka $20 \%$. Jauh dari harapan kuota 30\% keterwakilan perempuan sebagai salah satu langkah affirmative action untuk meningkatkan partisipasi politik perempuan dan cara khusus untuk mencapai kesetaraan gender dalam berpolitik. Artinya, dimaksudkan untuk mendorong keterlibatan perempuan dalam bidang politik. Affirmative action merupakan kebijakan yang dikeluarkan oleh pemerintah pertama kali melalui Undang-Undang No.12 tahun 2003 tentang pemilu anggota DPR, DPD dan DPRD. Sistem kuota adalah bentuk affirmative action yang harus dipenuhi partai dalam mengajukan calon anggota legislatif dan kepengurusan partai.

Namun, kuota keterwakilan perempuan tidak akan efektif jika pengetahuan, pemahaman dan keterampilan politik perempuan masih minim. Diharapkan perempuan yang terjun ke politik praktis baik yang menjadi kader biasa, pengurus partai maupun yang duduk dalam jabatan publik tidak hanya sekadar menjadi "pemanis" atau "pelengkap" tetapi mampu mengambil peran dan mempengaruhi pengambilan kebijakan politik. Dalam hasil penelitian Susiana \& Cahyaningrum (2010, hal. 27) mengungkapkan bahwa affirmative action yang terdapat dalam undang-undang pemilu belum dapat menjamin calon anggota legislatif perempuan untuk terpilih. Aturan tersebut masih perlu dilengkapi dengan aturan-aturan lain yang dapat menjamin agar calon anggota legislatif perempuan terpilih sehingga dapat meningkatkan keterwakilan perempuan di lembaga legislatif. Salah satu langkah strategis untuk mendukung kesuksesan pencapaian tujuan affirmative action ialah penekanan pada peranan partai politik dalam melaksanakan pendidikan politik kepada kader perempuan secara serius, terprogram, dan berkelanjutan.

Partai politik berperan penting dalam mendorong partisipasi politik dan peningkatan keterwakilan perempuan dalam kepengurusan internal partai dan lembaga legislatif karena perempuan memiliki pengalaman dan kepentingan yang berbeda dengan laki-laki. Selain itu, partai politik juga harus memberikan treatment untuk meningkatkan kompetensi perempuan untuk ikut dalam kompetisi politik dan meminimalisir kendala dalam pelaksanaan pendidikan politik yang berujung pada rendahnya partisipasi politik perempuan. Salah satu kendala yang kerap ditemui adalah persepsi buruk (stereotip) di tengah masyarakat seputar partisipasi dan keaktifan perempuan dalam politik praktis. Kesalahpahaman inilah yang berujung pada subordinasi perempuan dalam politik. Anggapan tersebut berakar pada masyarakat dengan budaya politik patriarki yang masih kental dan Indonesia masih masuk diantaranya (Muslimat, 2017; Warjiyati, 2016). Persepsi yang selama ini diteguhkan dalam benak masyarakat adalah konsepkonsep stereotip tentang perempuan di 
berbagai sektor, termasuk dalam sektor politik dan pemerintahan. Persepsi yang kebanyakan merupakan pelabelan tentang perempuan, akhirnya ditarik ke dunia publik termasuk di dunia politik bahwa perempuan tidak layak memimpin karena perempuan tidak rasional dan lebih mengandalkan emosinya yang menghalangi partisipasi dan representasi politik kader perempuan (Astuti, 2008; Wahid, 2013). Budaya patriarki di Indonesia kurang memberikan dukungan untuk perempuan berpartisipasi di ranah politik maupun pemerintahan. Selain itu, perempuan juga memiliki peran ganda jika memutuskan berkarier di dunia politik. Di satu sisi, mereka harus bersaing dengan lakilaki dalam kontestasi politik sehingga dapat membuktikan kapasitas dan kapabilitas nya serta di sisi lain mempunyai peran biologis sebagai seorang istri dan ibu di rumah.

Kader laki-laki dan perempuan memiliki interest tersendiri dalam menangani urusan publik. Politisi perempuan memiliki perhatian yang berbeda dengan politisi laki-laki, mereka cenderung memperhatikan kebutuhan-kebutuhan sosial yang sarat akan pelayanan publik seperti kesehatan masyarakat dibanding persoalan seputar pertahanan kekuasaan. Sejumlah hasil penelitian di beberapa negara, seperti di Amerika Serikat menyatakan bahwa tingginya angka representasi politik perempuan di parlemen berhubungan dengan kurangnya angka kematian bayi di Amerika Serikat pada periode 1990-2012, dan juga terjadi di daerah Bihar India disebabkan politisi perempuan fokus dalam mendorong kemajuan kesehatan masyarakat (Homan, 2017; Kumar \& Prakash, 2017). Kemudian, angka kepuasan hidup/kualitas hidup terbilang tinggi pada negara-negara dengan representasi politik perempuan yang juga tinggi karena salah satu indikator yang digunakan adalah pelayanan kesehatan masyarakat mendapat prioritas (York \& Bell, 2014). Namun juga diakui bahwa kepemimpinan perempuan tidak selalu mempengaruhi kebijakan-kebijakan politik seperti hasil penelitian di beberapa kota di Amerika serikat dimana posisi walikota perempuan tidak mempengaruhi ukuran pemerintahan lokal, pengeluaran daerah dan tingkat kejahatan. Meskipun demikian, perempuan yang menang dalam kontestasi politik adalah perempuan yang memiliki keterampilan politik yang superior dibandingkan dengan laki-laki (Ferreira \& Gyourko, 2014). Jadi, tidak didasarkan pada charity tetapi keterampilan politik politisi perempuan

Penelitian ini bertujuan untuk mendeskripsikan kendala dan upaya dalam pelaksanaan fungsi pendidikan politik kepada kader perempuan di Partai Nasional Demokrat (NASDEM) Dewan Pimpinan Wilayah Provinsi Sumatera Barat. Partai politik mempunyai kewajiban yuridis dan moral untuk melaksanakan pendidikan politik khususnya memberdayakan kader perempuan di tengah minimnya partisipasi politik perempuan.

\section{Metode}

Penelitian ini menggunakan pendekatan kualitatif dengan metode deskriptif yang dilakukan di Dewan Pimpinan Wilayah (DPW) Partai Nasdem Provinsi Sumatera Barat. Instrument penelitian adalah peneliti itu sendiri. Menurut Sugiyono (2013, hal. 305), human instrument berfungsi sebagai menetapkan fokus penelitian, memilih informan sebagai sumber data, melakukan pengumpulan data, menilai kualitas data, analisis data, menafsirkan data, dan membuat kesimpulan atas temuannya. Penentuan informan penelitian melalui teknik non probability sampling dengan teknik purposive sampling. Pengumpulan data melalui teknik wawancara dan dokumentasi. Analisis data meliputi reduksi data, penyajian data dan penarikan kesimpulan serta verifikasi. Teknik pengujian keabsahan data menggunakan triangulasi sumber

\section{Hasil dan Pembahasan}

Menilik posisi, peran, serta relasi perempuan dan politik, maka pembahasan akan tertuju pada konsep gender dan politik sebab persepsi gender mempengaruhi partisipasi perempuan dalam berpolitik. 
Gender berasal dari kata "gender" (Bahasa Inggris) yang diartikan sebagai jenis kelamin. Namun jenis kelamin di sini bukan seks secara biologis, melainkan sosial budaya dan psikologis. Pada prinsipnya konsep gender memfokuskan perbedaan peranan antara pria dengan wanita, yang dibentuk oleh masyarakat sesuai dengan norma sosial dan nilai sosial budaya masyarakat yang bersangkutan (Warjiyati, 2016). Gender bukanlah perbedaan berdasarkan jenis kelamin yang bersifat biologis dan tak bisa diubah melainkan perbedaan peranan yang dilekatkan oleh masyarakat kepada laki-laki dan perempuan sehingga (1) dapat diubah dengan upaya pelurusan persepsi; (2) peranan gender dapat berbeda dalam satu masyarakat dan masyarakat lainnya. Maskulin-feminin yang dilekatkan pada jenis kelamin laki-laki dan perempuan mempengaruhi tindakan masing-masing jenis kelamin dalam berpikir dan bertindak. Ketika terjun dalam politik praktis, perempuan harus menjadi dirinya sendiri, bertumpu pada pengetahuan, pengalaman dan keterampilan politiknya sehingga memberikan warna pada proses politik. Sidney Verba menyatakan bahwa sumbangan terpenting perempuan di dunia politik adalah mereka lebih berminat mengerjakan sesuatu yang bermanfaat bagi masyarakat daripada memperluas lingkup kekuasaan (Ballington \& Karam, 2005; Mulia \& Farida, 2005; Novianti, 2008; Zamroni, 2013).

Politik dan perilaku politik selama ini dipandang sebagai aktivitas maskulin. Perilaku politik yang lekat dengan sikap kemandirian, ketegasan, agresif, dan keras, dinilai tidak cocok dengan karakter perempuan yang digambarkan sebagai pribadi yang lemah lembut, pasrah dan penurut. Oleh karena itu, untuk meluruskan persepsi tersebut, partai politik sebagai suprastruktur politik di masyarakat, memainkan peran strategis dalam memberikan pendidikan politik kepada kader perempuan dan masyarakat. Namun, dalam realitas politik di lapangan, ditemukan beberapa kendala yang dihadapi partai politik dalam pelaksanaan pendidikan politik, seperti berikut:
Pertama, kendala utama yang dihadapi Partai Nasdem di DPW Sumatera Barat berasal dari sisi internal perempuan yakni rendahnya kepercayaan diri perempuan untuk bergabung dan terlibat aktif dalam politik praktis. Banyaknya kader perempuan sebuah partai politik tidak menjamin sebuah partai akan mudah untuk memenuhi kuota $30 \%$ keterwakilan perempuan di untuk masingmasing daerah pemilihan dalam pemajuan calon anggota legislatif. Ini bukanlah masalah satu partai politik saja melainkan kendala yang ditemui hampir setiap partai politik seIndonesia. Perempuan kurang tertarik untuk diberikan pelatihan dan pembinaan dalam peningkatan kapasitas di bidang politik praktis, mereka cenderung suka kegiatankegiatan santai seperti arisan dan berfotofoto. Oleh karena itu, partai politik harus berupaya keras untuk memberikan pendidikan politik guna membentuk kepribadian politik, kesadaran politik hingga memunculkan partisipasi politik kader perempuan. Hasil penelitian Amirullah (2016), dengan objek penelitian Partai Keadilan Sejahtera (PKS) terlihat bahwa bagi perempuan-perempuan PKS, politik bukan hanya seputar pemerintahan, sehingga mereka lebih memilih untuk fokus melakukan kerja-kerja internal partai, pemberdayaan ekonomi dan keluarga serta kajian-kajian Islam. Begitu juga di partai Golkar. Kebanyakan perempuan di Partai Golkar tidak begitu tertarik terhadap kegiatankegiatan yang bersifat politis dan tidak begitu antusias untuk terlibat ke dalam politik praktis seperti masuk ke dalam pemerintahan dan parlemen. Hal ini didasari pada anggapan bahwa kondisi yang terdapat di lapangan selama ini menunjukkan bahwa, penentu seseorang bisa menang dalam kontestasi pemilu adalah pada seberapa banyak uang yang dimiliki, bukan tergantung pada kualitas sehingga meningkatkan kualitas dan kapasitas di bidang politik tidak menjadi begitu penting.

Perempuan kurang memiliki motivasi yang kuat untuk ikut dalam proses politik dan enggan untuk menegaskan posisi politiknya serta menghindar dari lingkungan kompetitif. Mental perempuan belum terlatih dengan 
mental persaingan. Dunia politik lekat dengan kompetisi karena kegiatan partai sejak awal sudah didesain dengan kegiatan merebut, mempertahankan dan memperluas kekuasaan dengan cara-cara yang konstitusional untuk mewujudkan program/kebijakan berdasarkan platform politiknya. Salah satu penyebabnya adalah budaya patriarki politik dalam masyarakat (Amirullah, 2016; Mendelberg \& Karpowitz, 2016; Preece \& Stoddard, 2015).

Kedua, dukungan dan izin dari keluarga. Perempuan yang bekerja dan bergerak dalam segala macam aktivitas sosial politik harus mendapatkan izin keluarga. Kader perempuan yang berpotensi untuk memimpin dan aktif dalam kegiatan partai terkadang terkendala oleh izin keluarga. Jadi semuanya tidak bisa dinyatakan bahwa ketidakaktifan perempuan di partai adalah faktor kurangnya pengetahuan politik kader atau tidak melek politik. Izin keluarga juga terkait dengan masalah waktu. Kader perempuan cenderung sulit membagi waktu antara urusan keluarga dan kegiatan politik praktis di partai sehingga mempengaruhi partisipasinya dalam kegiatan dan program partai. Dalam partai politik, tidak ada jam kerja yang pasti. Perempuan yang aktif dalam politik praktis akan memiliki peran ganda, secara biologis menjadi istri dan ibu dalam ranah domestik serta secara moril dalam tanggung jawabnya sebagai pejabat publik.

Menurut hasil penelitian Andajani, Hadiwirawan, \& Sokang (2016), bahwa perempuan yang berkarier di luar rumah dalam hal ini pada tataran aktivitas politik praktis baik di kepartaian maupun di pemerintahan - mempunyai dua tantangan. Di satu sisi, ia harus berjuang menghadapi stigma masyarakat yang cenderung mendiskreditkan, artinya di sini ia harus pula memotivasi dirinya sendiri untuk tidak terpengaruh dengan stereotip yang ada dan di sisi lain perempuan harus pula menunjukkan kemampuannya untuk mengemban tugas dan mengelola organisasi. Ketika perempuan dihadapkan pada dua pilihan antara aktivitas politik di luar rumah atau fokus mengurus keluarga, pilihannya cenderung akan jatuh pada pilihan kedua. Namun, hal yang cukup menarik terjadi, jika masalah waktu disandingkan dengan faktor ekonomi. Tampaknya akan ditemukan fakta lain bahwa kader perempuan dengan kemampuan ekonomi yang mencukupi akan lebih aktif dari perempuan yang memiliki keterbatasan dalam keadaan keuangan. Hal ini dapat dimaklumi sebab perempuan dengan keadaan ekonomi yang cukup dapat menggunakan jasa pengasuh anak untuk merawat dan mengasuh anaknya ketika ia berkegiatan di luar rumah, berbeda halnya dengan perempuan yang datang dari keluarga sederhana bahkan kurang mampu. Mereka tentu akan mengurus anaknya sendiri karena tidak mampu menyewa jasa pengasuh anak bahkan perempuan ini harus bekerja di luar rumah untuk mencukupi kebutuhan ekonomi keluarga sehingga berkegiatan di partai diletakkan dalam urusan belakangan. Prioritas pertama bagi mereka adalah mencari nafkah atau mengasuh anak.

Berkegiatan di partai juga membutuhkan biaya sebab partai tidak selalu menyediakan dana akomodasi untuk kader. Partisipasi politik berupa keaktifan dalam kegiatan partai dipengaruhi oleh kendala pendanaan dalam mengikuti pendidikan politik di partai bagi kader perempuan. Meskipun begitu, terlepas dari mampu atau tidaknya seorang perempuan secara ekonomi, persoalan dana untuk kegiatan politik dapat menjadi satu kendala tersendiri. Jika partai telah membebaskan dana untuk kader yang maju dalam pemilihan umum guna bertarung untuk mendapatkan jabatan politik tertentu. Ia harus mampu membiayai dirinya sendiri, inilah salah satu kriteria yang dilihat oleh partai. Jika perempuan tidak bisa mencukupi secara ekonomi bagaimana ia akan membiayai kegiatan politik pencalonan. Dibutuhkan dukungan keluarga sebab dalam berpolitik dibutuhkan dana yang tidak sedikit. Artinya, Perempuan yang terjun dalam politik praktis melalui jalan yang panjang dan keras, diharuskan mendapatkan izin suami atau serta "keberkatan" dari partai politik.

Ketiga, budaya politik patriarki yang masih kental di masyarakat. Budaya patriarki merupakan pola dalam suatu sistem hubungan 
sosial yang di dalamnya didominasi oleh lakilaki, terdapat ketimpangan peran yang disebabkan oleh persepsi bahwa laki-laki lebih berkuasa atas perempuan karena menonjolkan kelemahan-kelemahan yang dimiliki perempuan. Dalam bidang sosial, bahkan di negara maju seperti Amerika, hal tersebut masih kental dimana posisi kepemimpinan perempuan dalam organisasi kelas pekerja terbilang sedikit padahal perempuan memainkan peran yang penting dalam perjuangan kelas pekerja. Budaya patriarki semakin kental terasa jika merambah pada dunia politik. Stereotip peran seksual menyatakan bahwa dunia politik adalah milik laki-laki. Persepsi politik jika dikaitkan dengan karakteristik perempuan maka akan ditemukan sebuah kontradiksi. Politik dipersepsikan sebagai dunia yang keras, kejam dan kotor sedangkan perempuan merupakan makhluk yang lemah. Posisi dan peranan perempuan menjadi minor ketika dihadapkan dengan peranan gender. Pengetahuan politik dan political efficacy laki-laki lebih tinggi daripada perempuan karena dibesarkan dengan budaya yang mendukung hal tersebut, justru kondisi stereotip demikian mengangkat political efficacy laki-laki. Political efficacy adalah istilah yang mengacu pada perasaan bahwa partisipasi politik seseorang memiliki dampak terhadap proses politik. Bila membicarakan peran politik perempuan, tidak bisa diartikan secara sempit seperti melihat politik dalam kaca mata formal di bidang legislatif, eksekutif dan yudikatif. Oleh karena eksistensi politik terwujud dalam aspek kehidupan bersama pada tingkat lokal maupun kepekaan terhadap permasalahan yang ada. Ikut atau tidaknya perempuan dalam bentuk partisipasi politik bergantung pada political efficacy (Martin, 2014; Mufti \& Syamsir, 2016; Nurcahyo, 2016; Pruysers \& Blais, 2014).

Perempuan yang aktif dalam politik kepartaian, dilandasi oleh beberapa alasan, diantaranya: pertama, hak politik merupakan bagian dari hak asasi manusia dan hak politik perempuan merupakan hak yang harus dilindungi, dihormati dan dipenuhi oleh negara dan diterima oleh masyarakat. Indonesia telah meratifikasi beberapa covenant internasional tentang pengakuan dan perlindungan hak-hak perempuan termasuk hak-hak politik. Jadi perempuan yang aktif berpolitik praktis dalam partai, sesungguhnya hanya menjalankan hak politik yang dimilikinya

Kedua, politik merupakan urusan setiap individu terlepas dari jenis kelamin dan peranan gender yang melekat dalam konstruksi sosial budaya masyarakat. Politik juga urusan perempuan. Politik termasuk kata yang paling banyak dibicarakan oleh masyarakat dimana pun dan kapan pun serta setiap orang memberikan definisi sesuai latar belakang keilmuan dan pengalamannya sehingga politik dapat dimaknai secara berbeda-beda. Berpolitik adalah sebuah keniscayaan dan setiap orang tidak dapat melepaskan diri dari politik sebab politik hadir di ruang publik mana pun (Darmawan, 2017). Selanjutnya dikatakan bahwa politik berkaitan dengan penunaian kewajiban, ideologi, dan wawasan pengetahuan masyarakat (Darmawan, 2017).

Ketiga, perempuan, sama seperti lakilaki-memiliki kebutuhan dan kepentingan politik yang harus diperjuangkan. Kedua hal ini cenderung lebih berhasil apabila diperjuangkan oleh perempuan sendiri sebab mereka lebih mengerti kebutuhan dan kepentingannya dibanding pihak lain. Jalur politik melalui partai politik merupakan jalur yang tepat untuk itu sebab politik lekat dengan kekuasaan dan tujuan utama partai politik adalah merebut dan mempertahankan kekuasaan untuk menerapkan kebijakan dan program-programnya. Partai politik adalah suatu kelompok organisasi yang anggotaanggotanya mempunyai orientasi, nilai-nilai dan cita-cita yang sama.

Keempat, kendala yang berasal dari internal partai politik. Persoalan dana pendidikan politik nyatanya masih menjadi kendala yang dirasakan oleh partai politik untuk melaksanakan pendidikan politik kader, sehingga cukup menghambat gerak partai dalam merencanakan dan melaksanakan program untuk 
memberdayakan kader. Setiap negara mempunyai kebijakan yang berbeda-beda mengenai pendanaan untuk partai politik. Pendanaan partai politik dapat diatur berasal dari iuran anggota maupun dari bantuan eksternal. Umumnya negara-negara di dunia, mengandalkan pendanaan partai pada sumbangan anggota. Besarnya biaya yang ditetapkan tergantung kebijakan internal partai politik masing-masing.

Pemerintah juga memberikan bantuan keuangan bagi partai politik. Bantuan tersebut utamanya ditujukan untuk pelaksanaan pendidikan politik bagi kader khususnya dan bagi masyarakat pada umumnya. Untuk alokasi dana bantuan dari pemerintah yang harus diberikan $60 \%$ untuk kegiatan pendidikan politik, Partai Nasdem menjawab bahwa pembiayaannya masih minim, partai mencoba mengurus rumah tangga dengan keadaan dan keterbatasan tersebut, artinya bersifat menyesuaikan. Tetapi tidak mungkin sebuah partai akan berhenti dalam pendidikan politik terutama untuk kader perempuan, walau bagaimanapun yang namanya sebuah partai pasti akan mandiri dan melakukan kegiatan pendidikan politik. Jika dibandingkan dengan kebutuhan tahunan partai, perbedaannya cukup jauh. Barangkali dari bantuan pemerintah cukup memfasilitasi $25 \%$ kebutuhan partai dari $100 \%$ untuk pendidikan politik. Dalam satu kegiatan pendidikan politik, Partai Nasdem menghabiskan puluhan bahkan ratusan juta rupiah. Satu kali kegiatan minimal 50-60 juta rupiah dengan dua hari kegiatan-kegiatan seperti seminar dan pelatihan dengan mendatangkan narasumber dan biaya akomodasi peserta pendidikan politik.

Kelima, kendala lainnya berasal dari regulasi hukum yang tidak tegas. Pemerintah memberikan bantuan keuangan kepada partai politik, dimana $60 \%$ dari dana bantuan tersebut harus dialokasikan untuk kegiatan pendidikan politik. Tetapi pemerintah tidak menegaskan sanksi bagi partai yang tidak melaksanakan pendidikan politik. Regulasi hukum di Indonesia tidak menghadirkan sanksi yang tegas untuk partai yang mengabaikan fungsi pendidikan politik bagi kader, dalam hal ini kader perempuan, padahal undang-undang partai politik, undang-undang tentang pemilihan legislatif serta peraturan perundang-undangan hasil ratifikasi beberapa konvensi terkait dengan perlindungan dan pemajuan peran perempuan dalam dunia politik merupakan landasan yuridis bagi kiprah perempuan dalam politik sekaligus menjadi pijakan bagi para pemangku kepentingan untuk membuat regulasi lebih lanjut dalam mendorong partisipasi perempuan; partai yang tidak secara serius mendukung kebijakan affirmative action berupa pemberdayaan kader perempuan partai guna meningkatkan partisipasi dan representasi politik perempuan di parlemen. Hal yang sama juga dinyatakan Kontu (2017), bahwa tidak ada sanksi yang tegas dalam pelaksanaan undang-undang yang mengatur mengenai kuota keterwakilan perempuan dalam parlemen dan posisi pengambil keputusan publik sehingga menjamin partisipasi perempuan dalam ranah politik.

Partai politik melakukan upaya-upaya untuk mengatasi berbagai kendala terhadap pelaksanaan pendidikan politik kader perempuan yang bertujuan untuk meningkatkan partisipasi politik kader perempuan partai. Upaya yang dilakukan diantaranya: pertama, partai melakukan pendekatan internal/personal. Partai mengedepankan cara-cara persuasif untuk menarik hati dan simpati kader perempuan guna aktif partisipatif dalam gerak politik. Pendekatan internal dilakukan untuk mengetuk kesadaran kader perempuan untuk menyadari peranannya sebagai warga negara yang memiliki hak, kewajiban dan tanggung jawab politik.

Partisipasi politik kader perempuan dalam partai politik tidak harus didefinisikan secara kaku dalam satu pandangan bahwa partisipasi politik berarti ambisi yang berlebihan dari kader perempuan untuk mencalonkan diri menjadi anggota legislatif, pemilihan kepala daerah dan wakil kepala daerah maupun pemilihan presiden dan wakil presiden. Partisipasi politik merupakan cerminan dari kepribadian politik dan 
kesadaran politik perempuan melaksanakan hak-hak politiknya. Bentuk partisipasi politik kader perempuan dalam partai politik memiliki konteks yang lebih luas yakni ikut menginisiasi dalam program/kegiatan partai; terlibat aktif dalam program/kegiatan partai; ikut dalam perdebatan menentukan kebijakan/sikap partai; aktif dalam kepengurusan partai; ikut serta menyukseskan program partai dalam lingkungan sosial masyarakatnya; mencalonkan diri dalam pemilihan legislatif/pemilihan kepala daerah dan/atau wakil kepala daerah serta pemilihan presiden dan/atau wakil presiden; memberikan pencerahan dan sosialisasi politik kepada masyarakat sebagai perpanjangan tangan partai dalam rangka melaksanakan fungsi-fungsi partai politik.

Kedua, pengembangan model pendidikan politik kader perempuan secara, terprogram, terstruktur dan berkesinambungan. Undangundang partai politik tidak memberikan patokan yang jelas mengenai mekanisme pengaderan partai sehingga tergantung kepada political will dan political action masing-masing partai politik. Pengaderan memegang peranan penting dalam pemberian pengetahuan, pemahaman dan keterampilan politik. Kaderisasi merupakan proses penyiapan sumber daya manusia agar kelak menjadi pemimpin yang mampu membangun peran dan fungsi organisasi secara lebih baik. Sedangkan rekrutmen politik merupakan jalan untuk menyaring, menyeleksi serta menempatkan kader pada jabatan politik baik di internal partai maupun pemerintahan. Untuk menjadi kader yang berkualitas dan terseleksi dalam mengisi jabatan-jabatan publik, perempuan kader partai harus mendapatkan pendidikan politik yang jelas, komprehensif dengan strategi, materi dan metode yang sesuai dengan kebutuhan perempuan itu sendiri.

Kegiatan pendidikan politik melalui pengaderan secara berjenjang dan berkelanjutan mempunyai beberapa kelebihan yaitu dapat menjadi alat ukur mengenai tingkat pengetahuan dan pemahaman politik kader; menjadi sarana yang efektif untuk memilih dan menentukan pilihan calon pemimpin guna menduduki jabatan publik; membangun dan meningkatkan ikatan emosional diantara sesama kader karena sistem pengaderan secara berjenjang biasanya akan dikoordinir oleh kader yang tingkatannya selalu berada di atas kader yang dibinanya; memiliki system keanggotaan yang jelas dengan mengutamakan kualitas kader bukan kuantitas kader. Pengaderan yang berjalan dengan baik menghasilkan kader perempuan yang cakap dan peka terhadap persoalan sosial politik di lingkungannya sehingga dapat mengikis budaya patriarki di tengahtengah masyarakat. Membuktikan kinerja kader perempuan bukan dengan teriakan belas kasihan untuk diakui tetapi melalui kemampuan dan kinerja nyata. Pendidikan politik terkait dengan pengaderan dilakukan dengan memperhatikan keadilan dan kesetaraan gender untuk membangun etika dan budaya politik sesuai dengan pancasila. Kesimpulan penelitian Reingold \& Harrell (2010) mengenai gender dalam politik sangat penting dan, dengan demikian kebutuhan partai politik, kelompok kepentingan, aktivis komunitas, pemimpin, teman, dan anggota keluarga dari semua garis untuk merekrut dan mendorong lebih banyak perempuan untuk mencalonkan diri untuk jabatan politik tetap kuat.

Kaderisasi dan perhatian partai terhadap perempuan tidak begitu saja selesai ketika partai telah membuat sebuah bidang untuk mengurusi pemberdayaan perempuan ataupun membentuk organisasi sayap khusus perempuan tetapi diperlukan koordinasi antara pengurus dan masing-masing serta pengurus-pengurus struktural partai baik di pusat, wilayah, daerah, hingga ke ranting. Pola kaderisasi dan rekrutmen politik yang jelas dapat meminimalisir dana pendidikan politik yang diberikan partai. Artinya, partai tidak hanya mengandalkan kegiatan-kegiatan seminar dan pelatihan-pelatihan dan workshop untuk mengasah keterampilan politik kader perempuan sebab kegiatan tersebut yang justru membutuhkan biaya politik yang mahal. Selain itu, kaderisasi secara jelas dan terencana merupakan upaya 
yang harus secara serius diperhatikan partai mengingat regulasi pemerintah terkait dengan kaderisasi begitu longgar. Kaderisasi merupakan bagian dari pendidikan politik di partai.

Ketiga, upaya untuk mengatasi kendala waktu, solusinya dengan menggelar rapat pada waktu-waktu yang dimungkinkan dapat dihadiri oleh kader perempuan dan waktu yang tidak terlalu disibukkan dengan keperluan rumah tangga. Selain itu, juga dilakukan upaya dalam hal mengonfirmasi kader perempuan jika akan ditugaskan untuk kegiatan partai yang dirasa akan memakan waktu yang lama dan berkemungkinan akan meninggalkan keluarganya

Keempat, dalam Partai Nasdem ada konsep tanpa mahar politik untuk kader yang maju dalam pemilihan umum. Ini merupakan bagian dari pendidikan politik untuk memberikan pencerdasan politik dan mengubah persepsi masyarakat bahwa politik merupakan suatu aktivitas yang mahal. Kebijakan tanpa mahar politik merupakan pengejawantahan dari semangat Restorasi Indonesia yang diusung Partai Nasdem. Dalam buku putih Restorasi Indonesia (2010) disebutkan bahwa Restorasi Indonesia mengandung arti suatu proses untuk mengembalikan, memperbaharui, mencerahkan, menata kembali, dan memperbaiki kondisi dalam perspektif jangka panjang yang terjadi dari dalam sistem itu sendiri dan dilakukan oleh seluruh komponen bangsa. Restorasi Indonesia mengandung dua dimensi yaitu dimensi moral, yang diperlukan karena terjadi kerusakan tatanan dan nilainilai yang sangat fundamental berupa pergeseran dari semangat perjuangan dan pengabdian serta sikap mental yang jujur menjadi sikap kepura-puraan, kecenderungan untuk mencari keuntungan pribadi tanpa peduli kerusakan sosial yang diakibatkan serta sikap materialis dan hedonis.

Gagasan tanpa mahar politik merupakan tagline Politik Partai Nasdem yang membedakannya dengan partai lain, bertujuan untuk meminimalisir kendala pendanaan politik bagi kader-kader partai potensial yang ingin maju dalam pemilihan umum. Jamak dipahami bahwa, pendanaan politik merupakan kendala umum yang ditemui hampir semua kader dalam partai politik di Indonesia. Akibatnya yang maju dan menang dalam pemilihan umum adalah kader yang memiliki modal politik yang besar akan tetapi minus prestasi dan berujung pada perbuatan korupsi untuk mengembalikan dana politik yang habis saat proses pencalonan.

Partisipasi kader perempuan di dalam kegiatan partai juga sangat dipengaruhi oleh dana. Tanpa dana yang cukup dan memadai mustahil bagi perempuan untuk bisa ikut secara total di dalam kegiatan partai. Partai politik memiliki peran dalam mencegah terjadinya kapitalisasi politik yang menyebabkan politisi bermental pragmatis dan membuat partai menjadi alat untuk mencapai kekuasaan semata dengan mengandalkan modal dana yang besar dalam perolehan suara konstituen. Politisi menang karena membeli suara rakyat (money politics) maka selama masa jabatannya hampir semuanya waktunya dipergunakan untuk mengembalikan biaya politik yang sudah dikeluarkan. Lalu kapan memikirkan nasib rakyat apalagi membangun daerahnya. Itulah konsekuensi pemasaran politik yang disalahartikan. Jaminan tanpa mahar politik terbukti mampu menarik kader perempuan untuk berpartisipasi dalam pencalonan anggota legislatif serta menjadi satu bentuk pendidikan politik bagi kader dan masyarakat.

\section{Simpulan}

Kendala-kendala dalam pelaksanaan pendidikan politik kader perempuan Partai Nasdem di DPW Sumatera Barat berasal dari sisi internal kader perempuan seperti rendahnya kepercayaan diri perempuan dalam berpolitik praktis, izin keluarga, pembiayaan kegiatan-kegiatan politik dan persoalan pembagian waktu antara kegiatan partai dan mengurus keluarga, keterbatasan dana partai politik dalam melaksanakan pendidikan politik; citra buruk (stereotip) dari masyarakat yang kurang permisif terhadap perempuan yang aktif berpartai dan; regulasi peraturan perundang-undangan yang tidak tegas 
mengatur sanksi bagi partai yang tidak serius melaksanakan pendidikan politik bagi kader perempuan. Keempat kendala tersebut mempengaruhi proses pencapaian tujuan pendidikan politik kader perempuan sehingga harus segera ditemukan win-win solution yang dapat diterima dan dijalankan oleh kader perempuan, masyarakat, partai politik dan bahan pertimbangan untuk mengubah regulasi hukum yang terkait dengan fungsi pendidikan politik kader partai. terdapat beberapa upaya untuk mengatasi kendala tersebut, diantaranya pendekatan internal, untuk mengetuk kesadaran politik perempuan; sistem pengaderan bagi kader perempuan yang terprogram, terstruktur dan berkesinambungan; waktu pelaksanaan kegiatan kepartaian yang mengakomodasi kepentingan perempuan; dan kebijakan jaminan tanpa mahar politik, dimana partai tidak meminta bayaran untuk dukungan yang diberikan partai ketika proses pencalonan kader dalam pemilu.

\section{Ucapan terima kasih}

Penulis mengucapkan terima kasih kepada lembaga pengelola dana pendidikan Republik Indonesia (LDPD RI) yang telah membiayai pelaksanaan penelitian ini. Selanjutnya, ucapan terima kasih kepada seluruh sivitas akademika Departemen Pendidikan Kewarganegaraan Sekolah Pascasarjana Universitas Pendidikan Indonesia sebagai lembaga akademik tempat penulis menuntut ilmu dalam jenjang magister.

\section{Referensi}

Amirullah, A. (2016). Pendidikan Politik Perempuan. Jurnal Visipena, 7(1), 104127.

Andajani, S., Hadiwirawan, O., \& Sokang, Y. A. (2016). Women's leaderships in Indonesia: current discussion, barriers, and existing stigma (Vol. 4).

Astuti, T. M. P. (2008). Citra Perempuan dalam politik. YINYANG Jurnal Studi Islam, Gender Dan Anak, 3(1), 3-16.
Ballington, J., \& Karam, A. (Eds.). (2005). Women in parliament: beyons numbers. A revise edition. Notes and Queries (Vol. s6-IV). Stockholm: International Institute for Democracy and Electoral Assistance. https://doi.org/10.1093/nq/s6IV.89.207-d

Branson, M. S., \& Quigley, C. N. (1998). The role of civic education. Washinton DC.

Darmawan, C. (2017). Optimalisasi fungsi peran DPR RI: perspektik ilmu politik. Bandung: Universitas Pendidikan Indonesia.

Ferreira, F., \& Gyourko, J. (2014). Does gender matter for political leadership? The case of US mayors. Journal of Public Economics, 112, 24-39.

Homan, P. (2017). Political gender inequality and infant mortality in the United States, 1990-2012. Social Science \& Medicine, 182, 127-135.

Katz, R. S., \& Crotty, W. (2014). Handbook partai politik. Bandung: Nusa Media.

Kontu, F. (2017). Representasi perempuan dalam politik lokal di era otonomi daerah. Societas: Jurnal Ilmu Administrasi Dan Sosial, 6(1), 34-46.

Kumar, S., \& Prakash, N. (2017). Effect of political decentralization and female leadership on institutional births and child mortality in rural Bihar,India (10780). IZA Discussion Papers (Vol. $185)$.

https://doi.org/10.1016/j.socscimed.20 17.04.013

Martin, A. W. (2014). Not just a man's world: women's political leadership in the American labor movement. Social Science Research, 46, 23-37.

Mendelberg, T., \& Karpowitz, C. F. (2016). Women's authority in political decision-making groups. The Leadership Quarterly, 27(3), 487-503.

Muchtarom, M. (2012). Strategi penguatan nilai-nilai Pancasila melalui inovasi pembelajaran PKn berorientasi civic knowledge, civic disposition and civic 
skill di perguruan tinggi. $P K n$ Progresif, 7(2), 114-130.

Mufti, M., \& Syamsir, A. (2016). Pembangunan politik. Bandung: Pustaka Setia.

Mulia, M., \& Farida, A. (2005). Perempuan dan politik. Jakarta: Gramedia Pustaka Utama.

Muslimat, A. (2017). Rendahnya partisipasi politik perempuan. Jurnal Studi Gender Dan Anak, 3(2), 17-30.

Novianti, I. (2008). Dilema kepemimpinan perempuan dalam Islam. Yinyang: Jurnal Studi Islam, Gender Dan Anak, 3(2), 255-261.

Nurcahyo, A. (2016). Relevansi budaya patriaki dengan partisipasi politik dan keterwakilan perempuan di parlemen. AGASTYA: JURNAL SEJARAH DAN PEMBELAJARANNYA, 6(1), 25-34.

Pamungkas, S., \& Parlindungan, U. (2011). Partai politik: teori dan praktik di Indonesia. Yogyakarta: Institute for Democracy and Welfarism.

Predescu, M., \& Darjan, I. (2010). Promoting political participation through adult education. Procedia - Social and Behavioral Sciences, 2(2), 3241-3245. https://doi.org/10.1016/j.sbspro.2010.0 3.495

Preece, J., \& Stoddard, O. (2015). Why women don't run: experimental evidence on gender differences in political competition aversion. Journal of Economic Behavior \& Organization, 117, 296-308.

Pruysers, S., \& Blais, J. (2014). Anything women can do men can do better: An experiment examining the effects of stereotype threat on political knowledge and efficacy. The Social Science Journal, 51(3), 341-349.

Reingold, B., \& Harrell, J. (2010). The impact of descriptive representation on women's political engagement. Political Research Quarterly, 63(2), 280-294.
Ruslan, U. A. M. (2000). Pendidikan politik Ikhwanul Muslimin. Solo: Era Intermedia.

Sugiyono. (2013). Penelitian campuran. Bandung: Alfabeta.

Susiana, S., \& Cahyaningrum, D. (2010). Implementasi pasal tentang affirmative action dalam Undang-Undang Nomor 10 tahun 2008 tentang Pemilu Anggota DPR, DPD, dan DPRD (studi di Provinsi Maluku Utara). Kajian, 14(3), 467-478.

Wahid, U. (2013). Perempuan dan kekuasaan politik dalam pemilukada DKI Jakarta tahun 2012. Jurnal Komunikasi: Malasysian Journal of Communication, 29(1), 73-97.

Warjiyati, S. (2016). Partisipasi politik perempuan perspektif hukum Islam. $A l$ Daulah: Jurnal Hukum dan Perlindungan Islam, 6(April), 1-27.

York, R., \& Bell, S. E. (2014). Life satisfaction across nations: the effects of women's political status and public priorities. Social Science Research, 48 , 48-61.

https://doi.org/10.1016/j.ssresearch.201 4.05.004

Zamroni, M. (2013). Perempuan dalam kajian komunikasi politik dan gender. Jurnal Dakwah, 14(1), 103-132. 